\title{
Small Heat Shock Protein16.3 of Mycobacterium tuberculosis: After Two Decades of Functional Characterization
}

\author{
Babban Jee $^{\mathrm{a}}$ Yogesh Singh ${ }^{\mathrm{b}}$ Renu Yadav ${ }^{\mathrm{c}}$ Florian Lang ${ }^{\mathrm{d}}$ \\ aDepartment of Health Research, Ministry of Health and Family Welfare, Government of India, New \\ Delhi, India, 'Institute of Medical Genetics and Applied Genomics, Eberhard-Karls-Tübingen University, \\ Tübingen,Germany 'Department of Biotechnology, Acharya Nagarjuna University, Guntur, India, \\ Institute of Physiology I, Eberhard-Karls-Tübingen University, Tübingen, Germany
}

\author{
Key Words \\ Mycobacterium tuberculosis $\cdot \mathrm{sHSP} 16.3 \cdot$ Dormancy • Vaccine $・$ Diagnosis $・$ Drug target
}

\begin{abstract}
Small heat shock proteins (sHSPs) are one of the five families of proteins acting as molecular chaperone. SHSPs possess a universally conserved alpha-crystallin domain, hence, also known as alpha-crystallin family. Mycobacterium tuberculosis (MTB) is an etiological agent of tuberculosis, a disease claiming million of lives every year across the world. MTB has two sHSPs: sHSP16.3 (a $16.3 \mathrm{kDa}$ protein) and Acr2 (a $17.8 \mathrm{kDa}$ protein). Of these, sHSP16.3 has been reported to be crucial for survival of MTB during prolonged period of dormancy, in addition to indispensable role in its growth, virulence and cell wall thickening. Additionally, this mycobacterial protein is also beneficial for host as well. Due to strong immunogenic properties and consistent presence in patients sera, SHSP16.3 has largely been implicated in vaccine development and diagnosis of latent and active infections of MTB in the clinical cases of TB. Recently, our study provided the substantial evidence to exploit this mycobacterial protein as a good drug target for developing novel therapeutic intervention. In the present review, a comprehensive analysis of various attributes of sHSP16.3 has been done and major gaps in area have been highlighted for future course of action.
\end{abstract}

\section{Introduction}

(C) 2018 The Author(s)

Published by S. Karger AG, Basel

Small heat shock proteins (sHSPs) are amongst the five major families of proteins known to function as molecular chaperone [1], produced either in response of mild shock of heat or other stresses [2]. sHSPs are ubiquitous in nature and found in both prokaryotic and eukaryotic systems. The backbone of members of this unique class of proteins possesses an evolutionarily conserved alpha-crystallin domain, a highly variable $\mathrm{N}$-terminal region and a more conserved short C-terminal region [1]. Further, it was found that alpha-crystallin

Dr. Babban Jee

and Prof. Florian Lang
Department of Health Research, Ministry of Health and Family Welfare, Government of India,

New Delhi-110001 (India); Tel. +91-11-23736216, Fax +91-11-23736221

E-Mail babbanjee_jalma@yahoo.com; florian.lang@uni-tuebingen.de 


\section{Cellular Physiology Cell Physiol Biochem 2018;49:368-380 \begin{tabular}{l|l|l} 
DOI: 10.1159/000492887 & $\begin{array}{l}\text { O 2018 The Author(s). Published by S. Karger AG, Basel } \\
\text { www.karger.com/cpb }\end{array}$
\end{tabular} \\ Jee et al.: sHSP16.3 of MTB}

domain contains many $\beta$-strands and forms classical seven - $\beta$-strand immunoglobulin like fold. Because of these structural features, it was proposed that the proteins of this heat shock proteins family may have relation to the immunoglobulin superfamily [3]. The sHSPs family is comparatively less conserved than other families of heat shock proteins including HSP60, HSP70 and HSP90 [4, 5]. The molecular mass of sHSP monomers varies between 12 to 43 $\mathrm{kDa}$ [6]. The individual member of this protein family is not only involved in protecting the denaturing nascent proteins from aggregation, but also in a wide range of cellular processes including protein homeostasis (proteostasis), muscle and cytoskeleton development, cell integrity, smooth muscle relaxation, cell cycle, anti-apoptosis, autophagy induction, mitochondrial energetic, genomic stability, cataract prevention and cardioprotection in eukaryotes [7, 8].

Mycobacterium tuberculosis (MTB) is an aerobic, non-motile and non-spore forming facultative bacterium causes tuberculosis, a major cause of worldwide mortality and morbidity. Annually, this bacterium kills 1.3 million people. Additionally, 6.3 million people have been reported to be infected with MTB every year. It is assumed that 5-15\% of MTB infected people develop active disease in their lifetime due to reactivation of infection [9]. MTB transmits through contact, hence, TB has been considered as one of the fatal contagious diseases. Although best therapeutic and preventive modalities are available, this bacterium is a major challenge before the world. And, reasons are its marvelous sensing ability, waxy cell envelope, slow-growing nature and smart genetic programming capability.

Dormancy is a major characteristic feature of MTB. It is a state, in which MTB shutdowns its many of vital metabolic activities and survives for a long time in its host by operating some key activities which are indispensable for its existence. Though before deciphering MTB whole genome sequence by Cole and his colleagues [10], it was believed to be entirely a physiological phenomenon but, it is now thought to be a well programmed event and regulated by number of factors. While hypoxia has been considered one of the prime driving forces behind the development of this phenomenon, small heat shock protein 16.3 (sHPS16.3) was found to be crucial for maintenance of dormancy in MTB. Hence, this protein has been termed dormancy protein [11]. Moreover, sHPS16.3 is a good candidate of drug development and vaccine $[12,13]$. In Table 1 , important information available on this protein has been summarized.

In this review, a comprehensive analysis has been done to examine the various features of sHPS16.3 not only from bacterial point-of view but also from host perspectives. At the end, major gaps in area have been pointed-out with some workable suggestions.

Table 1. Small heat shock protein16.3 of Mycobacterium tuberculosis: at a glance

\begin{tabular}{|c|c|}
\hline Protein name & Small heat shock protein 16.3 \\
\hline Belongs to & Small heat shock protein (HSP20) family \\
\hline Alternate name & HspX, Acr1 ( $\alpha$-crystallin related protein 1 ), Acr, HSP16.3, $16 \mathrm{kD}$ antigen, $14 \mathrm{kD}$ antigen, \\
\hline Encoded by gene & $h s p X / a c r / R v 2031 c$ \\
\hline Regulated by & $\begin{array}{c}\text { Two component system (TCS): DosR (DevR)-DosS-DosT ( also known as Rv3133c-Rv3132c- } \\
\text { Rv2027c) }\end{array}$ \\
\hline Gene location & Between $\mathrm{acg}$ and Rv2030c genes \\
\hline Protein length & 144 amino acids (aa) \\
\hline Gene length & 435 base pairs $(\mathrm{bp})$ \\
\hline Molecular mass & $16227 \mathrm{Da}$ \\
\hline Location & $2278.93 \mathrm{~Kb}$ \\
\hline $\begin{array}{l}\text { Synthesis } \\
\text { induced by }\end{array}$ & Stress \\
\hline Cellular location & Inner membrane, occurred outside of cell wall \\
\hline $\begin{array}{l}\text { Secreted } / \text { not } \\
\text { secreted }\end{array}$ & Secreted protein \\
\hline Functions as a & Molecular chaperone \\
\hline $\begin{array}{l}\text { Major role for } \\
\text { MTB }\end{array}$ & In survival, growth, virulence and cell wall thickening of MTB \\
\hline $\begin{array}{l}\text { Beneficial for } \\
\text { host as }\end{array}$ & Vaccine candidate, sero-and immuno-diagnostic marker, drug target \\
\hline
\end{tabular}




\section{MTB genome and small heat shock protein}

MTB possesses a circular chromosome of 4.4 megabase $(\mathrm{Mb})$ [14]. The genome of MTB comprises 4, 411, 529 base pairs and contains around 4, 000 genes. The genome is in rich of high guanine + cytosine content which is $65.6 \%$, insertion sequences, repetitive DNA, multigene family and duplicated housekeeping genes [10]. Of 4000 genes, genes Rv2031c (hspX) and Rv0251c (hsp) encode sHSPs16.3 and Acr2 (HrpA) small heat shock proteins respectively [15]. In the literature, there are many names of sHSPs16.3 including Acr, Acr1 ( $\alpha$-crystallin related protein1), HSP16.3, $16 \mathrm{kD}$ antigen and HspX. However, for the convenience, sHSP16.3 name has been used uniformly throughout the text.

\section{sHSP16.3 is a stress induced protein, not heat induced}

Like other members of sHSPs family protein, sHSP16.3 is not a heat induced protein as name implies but it is a hypoxia induced protein [11]. Presence of oxygen $[11,16$, 17], reactive nitrogen intermediates (RNIs) [18], vitamin C [19] and ingestion of MTB by macrophages have also been reported to upregulate the expression of its gene. Recently, our group demonstrated that when MTB infected murine macrophage is treated with exogenous IFN- $\gamma$ and IL-10, the expression of $h s p X$ is significantly modulated [20].

\section{Sub-cellular location of sHSP16.3}

The cellular location of MTB sHSP16.3 is unknown till date, although it appears to be peripherally associated with inner membrane [21] and occurred outside of the cell wall [22]. It was not found in culture supernatant [23, 24].

\section{Structure of sHSP16.3}

After spending more than 20 years (from the first reporting of function of sHSP16.3 in 1996 by Yuan and coworkers), it is very unfortunate that sHSP16.3 could not be crystallized. Thus, crystal structure of sHSP16.3 is still not available. However, in an electron cryomicroscopic examination, sHSP16.3 appeared as a triangular shaped particle consisting of three globules or lobes. On the basis of this finding, it was suggested that sHSP16.3 exists as a nonameric structure consisting of trimer of trimers, with a calculated total mass of 144.9 $\mathrm{kD}$ [25]. Later on, Berengian and co-workers (1999) confirmed that sHSP16.3 uses trimers as its building blocks to form a large nine-subunit oligomeric complex [26]. Kennaway and group (2005) showed that sHSP16.3 is a dodameric complex formed by tetrahedral arrangement of dimmers [27]. The way in which a sHSP16.3 oligomeric complex assembled and reassembled is well elucidated. It has been demonstrated that sHSP16.3 nonamers are assembled and reassembled via a stepwise process using trimer and hexamer intermediates $[28,29]$. Assembling process is initiated with formation of a dimer through interactions between two subunits of $\alpha$-crystallin domains followed by further interaction of this dimer to third subunit resulting in formation of an asymmetric trimer. Finally, this asymmetric trimer is assembled into symmetric nonamers through the interactions between $\mathrm{N}$-terminal and C-terminal domains [30].

sHSP16.3 of MTB is composed of 144 amino acids and has molecular mass of $16,277 \mathrm{Da}$ [31]. In subsequent time, its molecular mass was found to be 16, 227 Da [32]. The sHSP16.3 polypeptide possesses three domains like other members of sHSPs family proteins, a 85 residues long characteristic $\alpha$-crystallin domain flanked by a stretch of 41 residues nonconserved $\mathrm{N}$-terminal region followed by 16 residues long conserved $\mathrm{C}$ - terminal region $[30,33]$. 


\begin{tabular}{|c|c|}
\hline Cellular Physiology & Cell Physiol Biochem 2018;49:368-380 \\
\hline and Biochemistry & \begin{tabular}{l|l} 
DOI: 10.1159/000492887 \\
Published online: 23 August, 2018 & $\begin{array}{l}\text { O2018 The Author(s). Published by S. Karger AG, Basel } \\
\text { www.karger.com/cpb }\end{array}$
\end{tabular} \\
\hline
\end{tabular}

\section{Immunogenic property}

MTB sHSP16.3 was initially identified as a $14 \mathrm{kD}$ immunodominant antigen with strong immunogenic properties [31, 34, 35]. Later, monoclonal antibodies studies showed that sHSP16.3 antigen of MTB has specific B - cell [31] and T cells epitopes [36]. The antibody against sHSP16.3 has been found in about $70 \%$ of smear-positive patients with pulmonary tuberculosis (PTB) [37]. sHSP16.3 is recognized by both $\mathrm{CD}^{+}$and $\mathrm{CD}^{+} \mathrm{T}$ cells [38-40]. The most immunogenic peptide of sHSP16.3 is the 91-110 bp long sequence, recognized by $50 \%$ of the TB patients [36]. Further, it was observed that 91-110 immunogenic domain of sHSP16.3 comprises ${ }^{91}$ SEFAYGSFVRTVSL ${ }^{104}$ sequence which generates strong $\mathrm{T}$ cells responses in both human $\mathrm{T}$ cell clones and peripheral blood mononuclear cells (PBMCs) [41]. Previously, it was shown that peptide p91-110 contains specific T cells epitopes and exhibited high binding affinity with human leukocyte antigen (HLA)-DR (HLA-DRB1*0101, HLA-DRB1*1501 and HLA-DRB1*0401) [42]. Jurcevic and his co-workers showed that this MTB peptide binds with high affinity to HLA-DR1 and with moderate affinity to DR6 [43]. The peptide p91-110 not only binds to HLA-DR but also to DQ and DP molecules [44]. There are many other peptides such as p21-40 (HLA-DRB1*0401) [39], p21-29 and p120-128 (both HLA-A*0201) [45] which have been found to be immunogenic like peptide p91-110. Further investigation revealed that peptide p21-40 binds DR4 with only moderate affinity and DR3 with low affinity [43]. These all peptides were permissively recognized by human $\mathrm{T}$ cells $[39,45]$. It was observed that peptide p91-110 induces Th1 response through interaction with T cells. By contrast, p21-40 peptide stimulates the Th2 cells to produce IL-4 [39]. Thus, sHSP16.3 antigen favours production of both Th1 and Th2 cytokines. In a preliminary study, sHSP16.3 strongly elicited delayed type hypersensitivity (DTH) reaction in both mice and guinea pigs [46]. Available reports suggested that sHSP16.3 also has role in differentiation and proliferation of functionally distinct $T$ helper subsets [39, 42].

\section{Genomics and expression of $h s p X$}

As discussed earlier, sHSP16.3 is encoded by gene $h s p X$ (Rv2031c or $a c r$ ) [10]. This gene which is composed of 435 base pairs is located between acg and Rv2030c genes in MTB genome $[32,47]$. However, there is evidence that another gene is also present within this gene [48]. Sequencing analysis suggests that start codon (i.e. ATG) and stop codon (i.e. TGA) are situated at position 16 and 433 respectively in coding region of sHSP16.3. The ShineDalgarno (SD) sequence which is AGGAGG, was located 7 base pairs upstream of the ATG start codon [31]. The $h s p X$ gene has only one operon [49].

The expression of $h s p X$ mRNA was found high in log phase MTB. However, its cellular level was gradually decreased with shifting of bacterium to stationary phase [48]. Surprisingly, this decrease in mRNA accumulation whose half life is 2 minutes was accompanied by an increase in its translational rate. When tubercle bacillus is subjected to reverse step i.e. stationary phase to log phase, a rapid increase in the rate of transcription of $h s p X$ mRNA was noticed, but the synthesis of sHSP16.3 was remained unaffected, suggesting the presence of posttranscriptional control mechanism in the expression of $h s p X$ [48].

\section{Regulators of $h s p X$ expression}

Regulator of dormancy survival (DosR or DevR)-DosS-DosT (also known as Rv3133cRv3132c-Rv2027c), a bonafide two-component system (TCS) of MTB, is a major regulator that directly regulates the expression of $h s p X$ gene [49]. It comprised a response regulator (RR), DevR and two sensor histidine kinases, DosS and DosT which are susceptible to redox state and oxygen respectively $[50,51]$. Expression of $h s p X$ exclusively depends on $\operatorname{dos} R$ but not on the dosS (Rv3132c) sensor histidine kinase $[49,52]$. This finding was further 


\section{Cellular Physiology Cell Physiol Biochem 2018;49:368-380 \begin{tabular}{l|l|l} 
DOI: 10.1159/000492887 & $\begin{array}{l}\text { O } 2018 \text { The Author(s). Published by S. Karger AG, Basel } \\
\text { www.karger.com/cpb }\end{array}$
\end{tabular}

Fig. 1. Schematic representation of sHSP16.3 biology. After engulfment by macrophage, MTB resides in its phagosomal compartment where it faces various kinds of stresses. Upon exposure to stress, two component system (TCS) consisting of one response regulator DosR and two sensor kinases such as DosS and DosT is activated: firstly both senor histidine kinases DosS and DosT are get phosphorylated which in turn phosphorylate DosR. Phosphorylation of DosR resulted into up-regulation of sHSP16.3. There is evidence that the two component system is also under the control of another transcription regulator PhoP. MTB, Mycobacterium tuberculosis; sHSP16.3, Small heat shock protein16.3.

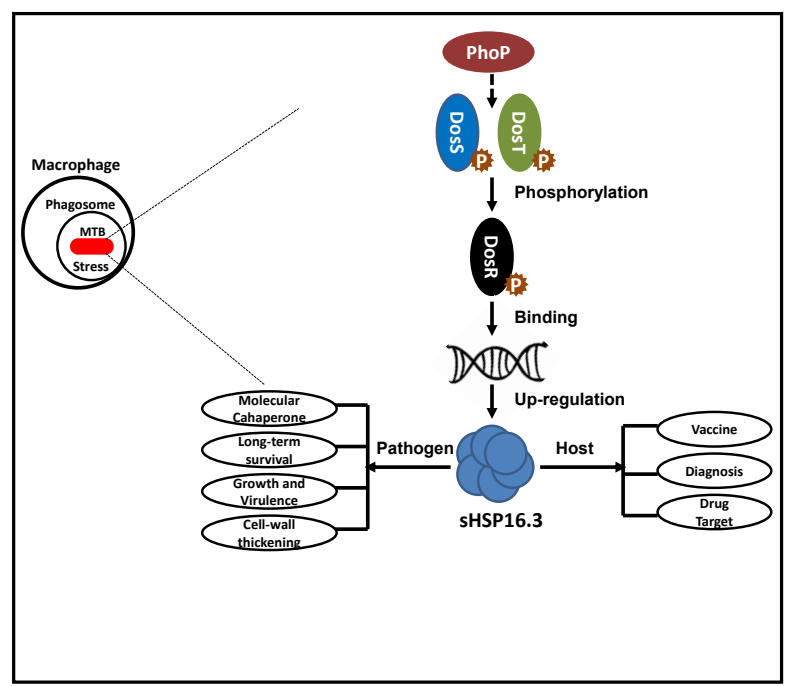

confirmed by O'Toole and his coworkers (2003) who showed that MTB which lacks $\operatorname{dev} R$ was not able to mediate stress response. On contrary, another report states that histidine kinase sensor plays an important role in mediating the hypoxic responses [53]. Under the hypoxic stress, both the sensor kinases are autophosphorylated which in turn lead to phosphorylation of response regulator DosR(DevR). Phosphorylated DosR then binds to upstream of $h s p X$ promoter DNA causing up-regulation of sHSP16.3 (Fig.1) [54].

The response regulator (DevR) of this two component system was first characterized in a H37RV virulent strain of MTB and found to be differentially expressed in H37RV strain in comparison of H37Ra avirulent strain, thus, it was named $\operatorname{dev} R$ (differentially expressed in the virulent strain) [50]. However, this nomenclature in subsequent time was changed and $\operatorname{dev} R$ was renamed $\operatorname{dos} R$ (regulator of dormancy survival) on account of its role in regulation of oxygen starvation-induced mycobacterial dormancy response in Mycobacterium bovis BCG [52]. Gene devR is composed of 654 base pairs encoding 217 amino acids translational product known as DevR. It shows homology to member of the NarL/UhpA/FixJ subfamily [50].

Gene $\operatorname{dev} R$ alongwith gene $h s p X$ and other co-transcribed 48 genes of MTB constitute a DosR/DevR dormancy regulon [54]. Except Mycobacterium leprae, almost all mycobacterial species possess DosR/DevR regulon [55]. The expression of this regulon is induced by a number of environmental stresses including hypoxia, nitric oxide, carbon monoxide, GSNO (NO donor), $\mathrm{H}_{2} \mathrm{O}_{2}$, ethanol, 30 min standing [49,51, 56-59], nutrient starvation [60] and microaerobic and anaerobic conditions [61]. The $\operatorname{dos} R / \operatorname{dev} R$ regulon is regulated by two component system DosR (DevR)-DosS-DosT. Interestingly, the response regulator DosR/ DevR and senor kinase DosS are also under the control of another transcriptional regulator phoP [62].

\section{Function of sHSP16.3}

\section{Chaperone activity}

The chaperone activity is a characteristics feature of sHSPs which attracted considerable attention of the workers from worldwide over the last two decades. Like other sHSPs, mycobacterial sHSP16.3 also exhibited its chaperonin property by preventing the thermal denaturation of alcohol dehydrogenase in vitro [11]. Similar finding was also reported by Chang and co-workers in 1996 [25]. For performing chaperone function, sHSP16.3 exposes its hydrophobic surfaces for interaction with denaturing proteins [63] and undergoes 
dissociation process [64]. Disturbance in native structures of sHSP16.3 and presence of amino acid leucine (Leu122) in protein backbone are also essential for chaperone like activity [64, 65], but ATP is not [11, 25, 63]. Valdez et al. (2002) reported that the presence of ATP in reaction not only enhanced the chaperone activity of MTB sHSP16.3 by two fold but also protects this MTB protein from proteolytic attack of chymotrypsin [66]. Moreover, chaperone activity of MTB sHSP16.3 is exclusively temperature dependent [67]. Even, pre-incubation of $\mathrm{sHSP} 16.3$ at $100^{\circ} \mathrm{C}$ resulted in enhanced chaperone like activity without altering the surface hydrophobicity [68].

\section{Survival of MTB during dormancy}

sHSP16.3 is a potentially important molecule of MTB, facilitating its survival during long-term dormancy $[11,22,66,69]$. It is synthesized in low quantity in early exponential phase cultures, but its cellular level increases when bacterium reaches stationary phase. The maximum synthesis of protein was observed during stationary phase [11]. Another study carried out by $\mathrm{Hu}$ and Coates (1999) suggested that sHSP16.3 is a stable protein, whose cellular presence was uniform through the culture period from 20 days to 50 days [48].

\section{Indispensable for growth and virulence of MTB}

Gene knockout studies indicated that sHSP16.3 is an inevitable requirement for normal growth of MTB during infection $[69,70]$. The deletion of gene $h s p X$ of MTB resulted in enhancement of bacterial growth whereas its overexpression slows the bacilli growth during early phase of mice infection. SHSP16.3 is also required for the virulence of MTB [70].

\section{Cell wall thickening}

sHSP16.3 has been found to be instrumental in cell wall thickening, thus facilitating dormancy indirectly as the thickened cell wall helps the bacilli to survive the hostile environment of host during actual course of infection [22].

\section{Usefulness of sHSP16.3 for host}

\section{Novel vaccine candidate}

sHSP16.3 has been widely exploited for enhancing the host immunity against MTB infection. An increasing amount of evidence is available which suggests its application as a novel candidate for vaccine design / formulation. In a number of experimental models, this mycobacterial antigen alongwith other antigens provided high level of protection to host against different phases of tuberculosis infection [13, 71-76]. However, its clinical application is currently awaited.

\section{Novel diagnostic marker}

The three characteristic features i.e. predominance in latency, specificity to MTB complex and frequent occurrence in sera of TB patients make this sHSP16.3 a new hope for clinicians to develop a novel immunodiagnostic strategy for early and rapid diagnosis of the latent infection of MTB in undefined cases of tuberculosis, in addition to its acute infection. There are substantial evidences which suggest that sHSP16.3 is a potent seroand immuno-diagnostic marker for accurate and early diagnosis of MTB in active and latent tuberculosis cases, when used alone or in combination with other MTB antigens [77-80].

\section{Novel drug target}

The current regimens for treatment of tuberculosis are lengthy, difficult to comply and significantly toxic [81]. Hence, it was felt since long time to develop new and better drugs / therapeutic modalities that would be more effective, shorter in length, tolerable and less toxic. With these goals, a more concerted effort was made during the last 
decades. As a result, some novel approaches of treatment for TB have been explored. Of these, host-directed therapy (HDT) and re-purposing of existing drugs have attracted considerable attention of the world [81-83]. Host-directed therapies rely either on the principle of modulating the specific host immune pathways or limiting the collateral tissue damage to be associated with pathogenesis of MTB. Unlike standard TB drugs, this therapeutic modality targets host proteins, hence, there is a lesser chance of development of antibiotic resistance in MTB [82]. In addition, many old drugs including oxazolidinones, $\beta$-lactams, clofazimine which were used for other clinical indications have also been repurposed for TB treatment. These repurposed drugs categorized as Group-5 agents by the World Health Organization have shown potential to treat both drug-susceptible and resistant strains of MTB [84], however, before routine application, their efficacy, dose, schedule, length of treatment, tolerability and toxicity are necessary to re-examine in various clinical settings.

In the way of discovery of new drugs that would be highly specific to MTB, whole genome sequencing of MTB and new computational technologies have played significant role. Today, many novel drug targets including proteins to be involved in amino acid biosynthesis, cofactor biosynthesis, mycothiol biosynthesis, DNA synthesis, glyoxylate shunt, oxidative phosphorylation, menaquinone biosynthesis and terpenoid biosynthesis are well known which are being targeted with both natural and synthetic compounds in order to develop MTB specific drugs [85-90]. Accumulating evidences also suggested that targeting of two component systems (TCSs) which have central role in the intracellular survival of MTB may be best option for drug discovery [91, 92].

As mentioned earlier, sHSPs primarily function as a molecular chaperone. In addition, sHSP plays a vital role in growth, survival and virulence of bacteria [93, 94]. As the fact that a sHSP interacts with a number of proteins (of diverse origin and nature) / regulatory partners (co-chaperones) during performing its action as a molecular chaperone; so, targeting a particular sHSP with potential inhibitor may lead to impair the function(s) of proteins supposed to be in its network. This multisite targeting is not possible with other non-sHSP molecules. Hence, these all factors/merits make this protein family a promising drug target. In recent few years, sHSPs have largely been implicated in drug development for developing the drugs of choice for various clinical conditions including cancer. Inhibition of HSP27 with small molecule inhibitors quercetin and RP101 has been proved to be an efficient way in combating the cancer. Of these, RP101 inhibitor is currently under advanced stages of clinical trial. RP101 has been found to be safe with no side-effects for cancer patients [95, 96]. Similar to HSP27, HSP70 and HSP90 have also been emerged as potential drug targets for cancer chemotherapy, although, they do not belong to sHSP family. Various inhibitors have been developed against these HSPs over the last few years and of these, some have entered clinical trials [97].

Like other sHSPs, the MTB sHSPs were not much explored from the perspectives of drug development. Hence, not much information is available on targeting of these proteins. However, some caseinolytic protein (Clp) group proteins (ClpC1, ClpP1 and ClpP2) which belong to heat shock protein HSP100 family of molecular chaperone and possess inherent ATPase activity [98, 99] have been targeted with a variety of compounds including cyclomarin A [100, 101], ecumicin [102], rufomycin [103], lassomycin [104], ADEP-2 [105, 106], N-(2-(3, 5-difluorophenyl)acetyl-Trp-boroMet), N-(Picolinoyl)-Ala-Lys-boroMet [107] and bortezomib (velcade) [108] in the past few years. Although the development of suitable inhibitors against these Clp proteins is in its early stage, the outcome of preliminary studies suggested that these inhibitors may be potential for MTB killing. Our group recently targeted sHSP16.3 using phytocompounds viz. ursolic acid and carvacrol by computational approaches. Findings of molecular docking analysis showed that both phytocompounds have strongly docked with sHSP16.3 and exhibited tendency to block the function of this crucial mycobacterial protein. Further, it was observed that both phytocompounds have strong binding ability to sHSP16.3 during whole 60 ns MD simulation time-frame. To further confirm the stability of protein-ligand complexes, we calculated the molecular 


\section{Cellular Physiology Cell Physiol Biochem 2018;49:368-380

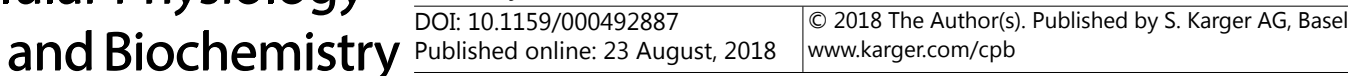 \\ Jee et al.: sHSP16.3 of MTB}

mechanic/ generalized Born/ Poisson-Boltzmann surface area (MM/G/P/BSA) free energies whose data showed that both ursolic acid and carvacrol have stable and favourable binding energies resulting in their strong binding to binding pocket of sHSP16.3 [12]. Previously, DevR, regulator of sHSP16.3, was targeted with phenylcoumarin derivative to produce the proof of concept for its importance as a novel drug target. The experimental data demonstrated that phenylcoumarin derivative inhibited the DevR binding to target DNA, down-regulated the expression of genes to be associated with dormancy and reduced the survival of hypoxic MTB [109].

\section{Existing gaps and Conclusion}

Although considerable amount of information is available on MTB dormancy protein sHSP16.3, its mechanism of action in natural state of MTB infection is not known. In addition, its role in evasion of the host-killing immune response has also not been elucidated. In view of the above lacunae, there is a necessity to demonstrate the chaperone function and role of sHSP16.3 in actual condition of infection, host-pathogen interaction and particularly in evasion of host immune mechanisms in vivo, so that further advanced strategy for killing the intracellular MTB using this protein could be developed.

\section{Acknowledgements}

This study was supported by the Open Access Publishing Fund of Eberhard-KarlsTübingen University, Germany.

\section{Disclosure Statement}

The authors declare no conflict of interest.

\section{References}

$>1$ de Jong WW, Caspers GJ, Leunissen JM: Genealogy of $\alpha$ crystallin-small heat shock protein superfamily. Int J Biol Macromol 1998;22:151-162.

2 Lindquist S, Craig EA: The heat shock proteins. Ann Rev Genet 1988;22:631-677.

3 Mornon JP, Halaby D, Malfois M, Durand P, Callebaut I, Tardieu A: $\alpha$-crystallin c-terminal domain: on the track of an Ig fold. Int J Biol Macromol 1998;22:219-227.

$>4$ de Jong WW, Leunissen JAM, Voorter CE: Evolution of the $\alpha$-crystallin/ small heat-shock protein family. Mol Biol Evol 1993;10:103-126.

5 Jakob U, Buchner J: Assisting spontaneity: the role of Hsp 90 and small Hsps as molecular chaperone. Trends Biochem Sci 1994;19:205-211.

-6 Ehrnsperger M, Lilie H, Gaestel M, Buchner J: The dynamics of Hsp25 quaternary structure. Structure and function of different oligomeric species. J Biol Chem 1999;274:14867-14874.

7 Bakthisaran R, Tangirala R, Rao ChM: Small heat shock proteins: role in cellular functions and pathology. Biochim Biophys Acta 2015;1854:291-319.

-8 Carra S, Alberti S, Arrigo PA, Benesch JL, Benjamin IJ, Boelens W, Bartelt-Kirbach B, Brundel BJJM, Buchner J, Bukau B, Carver JA, Ecroyd H, Emanuelsson C, Finet S, Golenhofen N, Goloubinoff P, Gusev N, Haslbeck M, Hightower LE, Kampinga HH et al.: The growing world of small heat shock proteins: from structure to functions. Cell Stress Chaperones 2017;22:601-611.

9 World Health Organization: Global Tuberculosis Report 2017. Geneva, WHO, 2017. 


\section{Cellular Physiology Cell Physiol Biochem 2018;49:368-380 and Biochemistry \begin{tabular}{l|l} 
DOI: 10.1159/000492887 & $\begin{array}{l}\text { O 2018 The Author(s). Published by S. Karger AG, Basel } \\
\text { www.karger.com/cpb }\end{array}$
\end{tabular} \\ Jee et al.: sHSP16.3 of MTB}

10 Cole ST, Brosch R, Parkhill J, Garnier T, Churcher C, Harris D, Gordon SV, Eiglmeier K, Gas S, Barry CE 3rd, Tekaia F, Badcock K, Basham D, Brown D, Chillingworth T, Connor R, Davies R, Devlin K, Feltwell T et al.: Deciphering the biology of Mycobacterium tuberculosis from the complete genome sequence. Nature 1998;393:537-544.

11 Yuan Y, Crane DD, Barry CE III: Stationary phase- associated protein expression in Mycobacterium tuberculosis: function of the mycobacterial alpha-crystallin homolog. J Bacteriol 1996;178:4484-4492.

-12 Jee B, Kumar S, Yadav R, Singh Y, Kumar A, Sharma N: Ursolic acid and carvacrol may be potential inhibitors of dormancy protein small heat shock protein16.3 of Mycobacterium tuberculosis. J Biomol Struct Dyn DOI: 10.1080/07391102.2017.1389305.

13 Chen L, Xu M, Wang ZY, Chen BW, Du WX, Su C, Shen XB, Zhao AH, Dong N, Wang YJ, Wang GZ: The development and preliminary evaluation of a new Mycobacterium tuberculosis vaccine comprising Ag85b, HspX and CFP-10:ESAT-6 fusion protein with CpG DNA and aluminum hydroxide adjuvants. FEMS Immunol Med Microbiol 2010;59:42-52.

14 Philipp WJ, Poulet S, Eiglmeier K, Pascopella L, Balasubramanian V, Heym B, Bergh S, Bloom BR, Jacobs WR Jr, Cole ST: An integrated map of the genome of the tubercle bacillus, Mycobacterium tuberculosis H37Rv, and comparison with Mycobacterium leprae. Proc Natl Acad Sci USA 1996;93:3132-3137.

15 Jee B, Katoch VM, Awasthi SK: Dissection of relationship between small heat shock proteins and mycobacterial diseases. Indian J Lepr 2008;80:231-245.

16 Desjardin LE, Hayes LG, Sohaskey CD, Wayne LG, Eisenach KD: Microaerophilic induction of the alphacrystallin chaperone protein homologue ( $h s p X)$ mRNA of Mycobacterium tuberculosis. J Bacteriol 2001;183:5311-5316.

17 Haile Y, Bjune G,Wiker HG: Expression of the mce A, esat-6 and hspX genes in Mycobacterium tuberculosis and their responses to aerobic conditions and to restricted oxygen supply. Microbiology 2002;148:38813886.

18 Garbe TR, Hibler NS, Deretic V: Response to reactive nitrogen intermediates in Mycobacterium tuberculosis: induction of the 16-kilodalton $\alpha$-crystallin homolog by exposure to nitric oxide donors. Infect Immun 1999;67:460-465.

19 Wang J, Zhou X, Zhang Z, Xu L, Yin X, Yang L, Zhao D: Effect of interaction of vitamin C on macrophage immune response to infection with Mycobacterium bovis. Cell Mol Biol (Noisy-le-grand) 2012;58(Suppl):OL1688-1694.

20 Jee B, Sharma P, Katoch K, Joshi B, Awasthi SK: IL-10 down-regulates the expression of survival associated gene hspX of Mycobacterium tuberculosis in murine macrophage. Braz J Infect Dis 2017;21:386-390.

21 Lee BY, Hefta SA, Brennan PJ: Characterization of the major membrane protein of virulent Mycobacterium tuberculosis. Infect Immun 1992;60:2066-2074.

22 Cunningham AF, Spreadbury CL: Mycobacterial stationary phase induced by low oxygen tension: cell wall thickening and localization of the 16-kilodalton $\alpha$-crystallin homolog. J Bacteriol 1998;180:801-808.

23 Abou-Zeid C, Smith I, Grange JM, Ratliff TL, Steele J, Rook GA: The secreted antigens of Mycobacterium tuberculosis and their relationship to those recognized by the available antibodies. J Gen Microbiol 1988;134:531-538.

-24 Verbon A, Kuijper S, Jansen HM, Speelman P, Kolk AH: Antigens in culture supernatant of Mycobacterium tuberculosis: epitopes defined by monoclonal and human antibodies. J Gen Microbiol 1990;136:955-964.

-25 Chang Z, Primm TP, Jakana J, Lee IH, Serysheva I, Chiu W, Gilbert HF, Quiocho FA: Mycobacterium tuberculosis 16-kDa antigen (Hsp16.3) functions as an oligomeric structure in vitro to suppress thermal aggregation. J Biol Chem 1996; 271:7218-7223.

26 Berengian AR, Parfenova M, Mchaourab HS: Site-directed spin labeling study of subunit interactions in the alpha-crystallin domain of small heat-shock proteins. Comparison of the oligomer symmetry in alphaAcrystallin, HSP 27, and HSP 16.3. J Biol Chem 1999;274:6305-6314.

27 Kennaway CK, Benesch JLP, Gohlke U, Wang L, Robinson CV, Orlova EV, Saibi HR, Keep NH: Dodecameric structure of the small heat shock protein Acr1 from Mycobacterium tuberculosis. J Biol Chem 2005;280:33419-33425.

28 Feng X, Huang S, Fu X, Abulimiti A, Chang Z: The reassembling process of the nonameric Mycobacterium tuberculosis small heat-shock protein Hsp16.3 occurs via a stepwise mechanism. Biochem J 2002;363:329334. 


\section{Cellular Physiology Cell Physiol Biochem 2018;49:368-380 \begin{tabular}{l|l|l} 
DOI: 10.1159/000492887 & $\begin{array}{l}\text { O 2018 The Author(s). Published by S. Karger AG, Basel } \\
\text { www.karger.com/cpb }\end{array}$
\end{tabular} \\ Jee et al.: sHSP16.3 of MTB}

29 Abulimiti A, Fu X, Gu L, Feng X, Chang Z: Mycobacterium tuberculosis Hsp16.3 nonamers are assembled and re-assembled via trimer and hexamer intermediates. J Mol Biol 2003;326:1013-1023.

30 Fu X, Zhang H, Zhang X, Cao Y, Jiao W, Liu C, Song Y, Abulimiti A, Chang Z: A dual role for the N-terminal region of Mycobacterium tuberculosis Hsp16.3 in self-oligomerization and binding denaturing substrate proteins. J Biol Chem 2005;280:6337-6348.

31 Verbon A, Hartskeerl RA, Schuitema A, Kolk AH, Young DB, Lathigra R: The 14, 000-molecular-weight antigen of Mycobacterium tuberculosis is related to the alpha-crystallin family of low-molecular- weight heat shock proteins. J Bacteriol 1992;174:1352-1359.

32 TubercuList: http://genolist.pasteur.fr/TubercuList/ (accessed 09 March 2018).

-33 Leroux MR, Milki R, Gordon B, Batelier G, Candido EP: Structure-function studies on small heat shock protein oligomeric assembly and interaction with unfolded polypeptides. J Biol Chem 1997;272:2464624656.

-34 Engers HD, Houba V, Bennedsen J, Buchanan TM, Chaparas SD, Kadival G, Closs O, David JR, van Embden JDA, Godal T, Mustafa SA, Ivanyi J, Young DB, Kaufmann SH, Khomenko AG, Kolk AH, Kubin M, Louis JA, Minden P, Shinnick TM, Trnka L, Young RA: Results of a world health organization-sponsored workshop to characterize antigens recognized by Mycobacterium-specific monoclonal antibodies. Infect Immun 1986;51:718-720.

35 Jackett PS, Bothamley GH, Batra HV, Mistry A, Young DB, Ivanyi J: Specificity of antibodies to immunodominant mycobacterial antigens in pulmonary tuberculosis. J Clin Microbiol 1988;26:2313-2318.

-36 Friscia G, Vordermeier HM, Pasvol G, Harris D, Moreno C, Ivanyi J: Human T cell responses to peptide epitopes of the $16 \mathrm{kD}$ antigen in tuberculosis. Clin Exp Immunol 1995;102:53-57.

-37 Bothamley GH, Rudd R, Festenstein F, Ivanyi J: Clinical value of the measurement of Mycobacterium tuberculosis specific antibody in pulmonary tuberculosis. Thorax 1992;47:270-275.

-38 Oftung F, Borka E, Mustafa AS: Mycobacterium tuberculosis reactive T cell clones from naturally converted PPD-positive healthy subjects: recognition of the M. tuberculosis 16-kDa antigen. FEMS Immunol Med Microbiol 1998;20:319-325.

-39 Agrewala JN, Wilkinson RJ: Differential regulation of Th1 and Th2 cells by p91- 110 and p21-40 peptides of the 16-kD $\alpha$-crystallin antigen of Mycobacterium tuberculosis. Clin Exp Immunol 1998;114:392-397.

-40 Commandeur S, Lin MY, van Meijgaarden KE, Friggen AH, Franken KL, Drijfhout JW, Korsvold GE, Oftung F, Geluk A, Ottenhoff TH: Double- and monofunctional CD4 ${ }^{+}$and $\mathrm{CD}^{+}{ }^{+}$T-cell responses to Mycobacterium tuberculosis DosR antigens and peptides in long-term latently infected individuals. Eur J Immunol 2011;41:2925-2936.

41 Bosze S, Caccamo N, Majer Z, Mezo G, Dieli F, Hudecz F: In vitro T-cell immunogenicity of oligopeptides derived from the region 92-110 of the 16-kDa protein of Mycobacterium tuberculosis. Biopolymers 2004;76:467-476.

42 Agrewala JN, Wilkinson RJ: Influence of HLA-DR on the phenotype of CD4+ T lymphocytes specific for an epitope of the 16-kDa $\alpha$-crystallin antigen of Mycobacterium tuberculosis. Eur J Immunol 1999;29:17531761.

43 Jurcevic S, Hills A, Pasvol G, Davidson RN, Ivanyi J, Wilkinson RJ: T cell responses to a mixture of Mycobacterium tuberculosis peptides with complementary HLA-DR binding profiles. Clin Exp Immunol 1996;105:416-421.

-44 Andersson L, Gustafsson K, Jonsson AK, Rask L: Concerted evolution in a segment of the first domain exon of polymorphic MHC class II $\beta$ loci. Immunogenetics 1991;33:235-242.

45 Caccamo N, Milano S, Di Sano C, Cigna D, Ivanyi J, Krensky AM, Dieli F, Salerno A: Identification of epitopes of Mycobacterium tuberculosis 16-kDa protein recognized by human leukocyte antigen-A*0201 CD8(+) T lymphocytes. J Infect Dis 2002;186:991-998.

46 Kingston AE, Salgame PR, Mitchism NA, Colston MJ: Immunological activity of a 14-kilodalton recombinant protein of Mycobacterium tuberculosis H37Rv. Infect Immun 1987;55:3149-3154.

47 Hu Y, Coates AR: Mycobacterium tuberculosis acg gene is required for growth and virulence in vivo. PLoS One 2011;6:e20958. DOI: 10.1371/journal.pone.0020958.

$\checkmark 48$ Hu Y, Coates AR: Transcription of the stationary-phase-associated hspX gene of Mycobacterium tuberculosis is inversely related to synthesis of the 16-kilodalton protein. J Bacteriol 1999;181:1380-1387. 


\section{Cellular Physiology Cell Physiol Biochem 2018;49:368-380 \begin{tabular}{l|l|l} 
DOI: 10.1159/000492887 & $\begin{array}{l}\text { O } 2018 \text { The Author(s). Published by S. Karger AG, Basel } \\
\text { www.karger.com/cpb }\end{array}$
\end{tabular} \\ Jee et al.: SHSP16.3 of MTB}

49 Sherman DR, Voskuil MI, Schnappinger D, Liao R, Harrell MI, Schoolnik GK: Regulation of the Mycobacterium tuberculosis hypoxic response gene encoding $\alpha$-crystallin. Proc Natl Acad Sci USA 2001;98:7534-7539.

50 Dasgupta N, Kapur V, Singh KK, Das TK, Sachdeva S, Jyothisri K, Tyagi JS. Characterization of a twocomponent system, devR-devS, of Mycobacterium tuberculosis. Tuber Lung Dis 2000;80:141-159.

51 Saini DK, Malhotra V, Dey D, Pant N, Das TK, Tyagi JS: DevR-DevS is a bona fide two-component system of Mycobacterium tuberculosis that is hypoxia-responsive in the absence of the DNA-binding domain of DevR. Microbiology 2004;150:865-875.

52 Boon C, Dick T: Mycobacterium bovis BCG response regulator essential for hypoxic dormancy. J Bacteriol 2002;184:6760-6767.

53 O’Toole R, Smeulders MJ, Blokpoel MC, Kay EJ, Lougheed K, Williams HD: A two-component regulator of universal stress protein expression and adaptation to oxygen starvation in Mycobacterium smegmatis. J Bacteriol 2003;185:1543-1554.

54 Park HD, Guinn KM, Harrel MI, Liao R, Voskuil MI, Tompa M, Schoolnik GK, Sherman DR: Rv3133c/dosR is a transcription factor that mediates the hypoxic response of Mycobacterium tuberculosis. Mol Microbiol 2003;48:833-843.

55 Gerasimova A, Kazakov AE, Arkin AP, Dubchak I, Gelfand MS: Comparative genomics of the dormancy regulons in mycobacteria. J Bacteriol 2011;193:3446-3452.

56 Ohno H, Zhu G, Mohan VP, Chu D, Kohno S, Jacobs WR Jr, Chen J: The effects of reactive nitrogen intermediates on gene expression in Mycobacterium tuberculosis. Cell Microbiol 2003;5:637-648.

-57 Voskuil MI, Schnappinger D, Visconti KC, Harrell MI, Dolganov GM, Sherman DR, Schoolnik GK: Inhibition of respiration by nitric oxide induces a Mycobacterium tuberculosis dormancy program. J Exp Med 2003;198:705-713.

58 Kendall SL, Movahedzadeh F, Rison SC, Wernisch L, Parish T, Duncan K, Betts JC, Stoker NG: The Mycobacterium tuberculosis dosRS two-component system is induced by multiple stresses. Tuberculosis (Edinburgh) 2004;84:247-255.

-59 Kumar A, Toledo JC, Patel RP, Lancaster Jr JR, Steyn AJ: Mycobacterium tuberculosis DosS is a redox sensor and DosT is a hypoxia sensor. Proc Natl Acad Sci USA 2007;104:11568-11573.

60 Betts JC, Lukey PT, Robb LC, McAdam RA, Duncan K: Evaluation of a nutrient starvation model of Mycobacterium tuberculosis persistence by gene and protein expression profiling. Mol Microbiol 2002;43:717-731.

61 Mayuri, Bagchi G, Das TK, Tyagi JS: Molecular analysis of the dormancy response in Mycobacterium smegmatis: expression analysis of genes encoding the DevR-DevS two-component system, Rv3134c and chaperone alpha-crystallin homologues. FEMS Microbiol Lett 2002;211:231-237.

62 Gonzalo-Asensio J, Mostowy S, Harders-Westerveen J, Huygen K, Hernández-Pando R, Thole J, Behr M, Gicquel B, Martín C: PhoP: a missing piece in the intricate puzzle of Mycobacterium tuberculosis virulence. PLoS One 2008;3:e3496.

-63 Yang H, Huang S, Dai H, Gong Y, Zhang C, Zhang Z: The Mycobacterium tuberculosis small heat shock protein HSP16.3 exposes hydrophobic surfaces at mild conditions: conformational flexibility and molecular chaperone activity. Protein Sci 1999;8:174:179.

64 Fu X, Liu C, Liu Y, Feng X, Gu L, Chen X, Chang Z: Small heat shock protein Hsp16.3 modulates its chaperone activity by adjusting the rate of oligomeric dissociation. Biochem Biophys Res Commun 2003;310:412:420.

65 Dai H, Mao Q, Yang H, Huang S, Chang Z: Probing the roles of the only universally conserved leucine residue (Leu122) in the organization and chaperone-like activity of Mycobacterium tuberculosis small heat shock protein Hsp16.3. J Protein Chem 2000;19:319-326.

66 Valdez MM, Clark JI, Wu GJS, Muchowski PJ: Functional similarities between the small heat shock proteins Mycobacterium tuberculosis HSP16.3 and human $\alpha \beta$-crystallin. Eur J Biochem 2002;269:1806-1813.

-67 Fu X, Chang Z: Temperature-dependent subunit exchange and chaperone-like activities of Hsp16.3, a small heat shock protein from Mycobacterium tuberculosis. Biochem Biophys Res Commun 2004;316:219-299.

68 Mao Q Ke D, Chang Z: Electrostatic interactions play a critical role in Mycobacterium tuberculosis Hsp16.3 binding of substrate proteins. Biochemistry 2001;66:904-908.

69 Yuan Y, Crane DD, Simpson RM, Zhu YQ, Hickey MJ, Sherman DR, Barry CE III: The 16-kDa alpha-crystallin (Acr) protein of Mycobacterium tuberculosis is required for growth in macrophages. Proc Natl Acad Sci USA 1998;95:9578-9583. 


\section{Cellular Physiology Cell Physiol Biochem 2018;49:368-380 and Biochemistry \begin{tabular}{l|l} 
DOI: 10.1159/000492887 & $\begin{array}{l}\text { O 2018 The Author(s). Published by S. Karger AG, Basel } \\
\text { www.karger.com/cpb }\end{array}$
\end{tabular} \\ Jee et al.: sHSP16.3 of MTB}

70 Hu Y, Movahedzadeh F, Stoker NG, Coates AR: Deletion of the Mycobacterium tuberculosis $\alpha$-crystallin-like $h s p X$ gene causes increased bacterial growth in vivo. Infect Immun 2006;74:861-868.

71 Chen L, Xu M, Du WX, Chen BW, Wang ZY, Wang YJ, Dong N, Su C, Shen XB, Wang GZ: [Preparation of two antigens - Ag85b and HspX of Mycobacterium tuberculosis H37Rv and the effects of their co-administration with adjuvants in mice]. Zhongguo Yi Xue Ke Xue Yuan Xue Bao 2009;31:403-409.

72 Shi C, Chen L, Chen Z, Zhang Y, Zhou Z, Lu J, Fu R, Wang C, Fang Z, Fan X: Enhanced protection against tuberculosis by vaccination with recombinant BCG over-expressing HspX protein. Vaccine 2010;28:52375244 .

-73 Jeon BY, Kim SC, Eum SY, Cho SN: The immunity and protective effects of antigen 85A and heat-shock protein X against progressive tuberculosis. Microbes Infect 2011;13:284-290.

74 Li Q Yu H, Zhang Y, Wang B, Jiang W, Da Z, Xian Q, Wang Y, Liu X, Zhu B: Immunogenicity and protective efficacy of a fusion protein vaccine consisting of antigen Ag85B and HspX against Mycobacterium tuberculosis infection in mice. Scand J Immunol 2011;73:568-576.

75 Niu H, Hu L, Li Q, Da Z, Wang B, Tang K, Xin Q, Yu H, Zhang Y, Wang Y, Ma X, Zhu B: Construction and evaluation of a multistage Mycobacterium tuberculosis subunit vaccine candidate Mtb10.4-HspX. Vaccine 2011;29:9451-9458.

76 Yuan W, Dong N, Zhang L, Liu J, Lin S, Xiang Z, Qiao H, Tong W, Qin C: Immunogenicity and protective efficacy of a tuberculosis DNA vaccine expressing a fusion protein of Ag85B-Esat6-HspX in mice. Vaccine 2012;30:2490-2497.

77 Wu X, Yang Y, Zhang J, Li B, Liang Y, Zhang C, Dong M: Comparison of antibody responses to seventeen antigens from Mycobacterium tuberculosis. Clin Chim Acta 2010;411:1520-1528.

78 Zhang C, Song X, Zhao Y, Zhang H, Zhao S, Mao F, Bai B, Wu S, Shi C: Mycobacterium tuberculosis secreted proteins as potential biomarkers for the diagnosis of active tuberculosis and latent tuberculosis infection. J Clin Lab Anal 2015;29:375-382.

-79 Zagmignan A, Costa ACD, Viana JL, Lima Neto LG, Monteiro CA, Gaioso Neto AG, Junqueira-Kipnis AP, de Sousa EM: Identification of specific antibodies against the Ag85C-MPT51-HspX fusion protein (CMX) for serological screening of tuberculosis in endemic area. Expert Rev Clin Immunol 2017; 13:837-843.

-80 Kasempimolporn S, Thaveekarn W, Promrungreang K, Khow 0, Boonchang S, Sitprija V: Improved serodiagnostic sensitivity of strip test for latent tuberculosis. J Clin Diagn Res 2017;11:DC01-DC03.

81 Wong EB, Cohen KA, Bishai WR: Rising to the challenge: new therapies for tuberculosis. Trends Microbiol 2013;21:493-501.

82 Tobin DM: Host-directed therapies for tuberculosis. Cold Spring Harb Perspect Med 2015;5:a021196.

83 Tiberi S, du Plessis N, Walzl G, Vjecha MJ, Rao M, Ntoumi F, Mfinanga S, Kapata N, Mwaba P, McHugh TD, Ippolito G, Migliori GB, Maeurer MJ, Zumla A: Tuberculosis: progress and advances in development of new drugs, treatment regimens, and host-directed therapies. Lancet Infect Dis 2018;18:e183-198.

-84 Dooley KE, Obuku EA, Durakovic N, Belitsky V, Mitnick C, Nuermberger EL; Efficacy Subgroup, RESIST-TB: World Health Organization group 5 drugs for the treatment of drug-resistant tuberculosis: unclear efficacy or untapped potential? J Infect Dis 2013;207:1352-1358.

-85 Zhang Y: The magic bullets and tuberculosis drug targets. Annu Rev Pharmacol Toxicol 2005;45:529-564.

-86 Lou Z, Zhang X: Protein targets for structure-based anti-Mycobacterium tuberculosis drug discovery. Protein Cell 2010;1:435-442.

87 Mdluli K, Kaneko T, Upton A: The tuberculosis drug discovery and development pipeline and emerging drug targets. Cold Spring Harb Perspect Med 2015;5:a021154.

-88 Bald D, Villellas C, Lu P, Koul A: Targeting energy metabolism in Mycobacterium tuberculosis, a new paradigm in antimycobacterial drug discovery. mBio 2017; 8:e00272-17.

89 Singh V, Mizrahi V: Identification and validation of novel drug targets in Mycobacterium tuberculosis. Drug Dis Today 2017;22:503-509.

-90 Wellington S, Hung DT: The expanding diversity of Mycobacterium tuberculosis drug targets. ACS Infect Dis 2018;11:696-714.

91 Marszalek M, Planas A, Pellicer T: Two-Component Systems of Mycobacterium tuberculosis as potential targets for drug development. AFINIDAD LXXI 2014:567.

92 Banerjee SK, Kumar M, Alokam R, Sharma AK, Chatterjee A, Kumar R, Sahu SK, Jana K, Singh R, Yogeeswari P, Sriram D, Basu J, Kundu M: Targeting multiple response regulators of Mycobacterium tuberculosis augments the host immune response to infection. Sci Rep 2016;6:25851. 


\section{Cellular Physiology Cell Physiol Biochem 2018;49:368-380 and Biochemistry \begin{tabular}{l|l} 
DOI: 10.1159/000492887 & $\begin{array}{l}\text { O 2018 The Author(s). Published by S. Karger AG, Basel } \\
\text { www.karger.com/cpb }\end{array}$
\end{tabular} \\ Jee et al.: SHSP16.3 of MTB}

93 Henderson B, Allan E, Coates AR: Stress wars: the direct role of host and bacterial molecular chaperones in bacterial infection. Infect Immun 2006;74:3693-3706.

94 Chang Z: Understanding what small heat shock proteins do for bacterial cells; in Tanguay R, Hightower L (eds): The Big Book on Small Heat Shock Proteins. Heat Shock Proteins. Cham, Springer, 2015, vol 8.

$\$ 95$ Heinrich JC, Tuukkanen A, Schroeder M, Fahrig T, Fahrig R: RP101 (brivudine) binds to heat shock protein HSP27 (HSPB1) and enhances survival in animals and pancreatic cancer patients. J Cancer Res Clin Oncol 2011:137:1349-1361.

96 McConnell JR, McAlpine SR: Heat shock proteins 27, 40, and 70 as combinational and dual therapeutic cancer targets. Bioorganic Med Chem Lett 2013:23:1923-1928.

$\$ 97$ Chatterjee S, Burns TF: Targeting heat shock proteins in cancer: a promising therapeutic approach. Int J Mol Sci 2017;18:1978.

$\$ 98$ Squires C, Squires CL: The Clp proteins: proteolysis regulators or molecular chaperones? J Bacteriol 1992;174:1081-1085.

$\$ 99$ Schirmer EC, Glover JR, Singer MA, Lindquist S: HSP100 / Clp proteins: a common mechanism explains diverse functions. Trends Biochem Sci 1996:21:289-296.

100 Schmitt EK, Riwanto M, Sambandamurthy V, Roggo S, Miault C, Zwingelstein C, Krastel P, Noble C, Beer D, Rao SP, Au M, Niyomrattanakit P, Lim V, Zheng J, Jeffery D, Pethe K, Camacho LR: The natural product cyclomarin kills Mycobacterium tuberculosis by targeting the ClpC1 subunit of the caseinolytic protease. Angew Chem Int Ed Engl 2011;50:5889-5891.

101 Vasudevan D, Rao SP, Noble CG: Structural basis of mycobacterial inhibition by cyclomarin A. J Biol Chem 2013;288:30883-30891.

102 Gao W, Kim JY, Anderson JR, Akopian T, Hong S, Jin YY, Kandror O, Kim JW, Lee IA, Lee SY, McAlpine JB, Mulugeta S, Sunoqrot S, Wang Y, Yang SH, Yoon TM, Goldberg AL, Pauli GF, Suh JW, Franzblau SG, Cho $\mathrm{S}$ : The cyclic peptide ecumicin targeting ClpC1 is active against Mycobacterium tuberculosis in vivo. Antimicrob Agents Chemother 2015;59:880-889.

103 Choules M, Yu Y, Cho SH, Anderson J, Gao W, Klein L, Lankin DC, Kim JY, Cheng J, Yang SH, Lee H, Suh JW, Franzblau SG, Pauli GF: A rufomycin analogue is an anti-tuberculosis drug lead targeting CLPC1 with no cross resistance to ecumicin. Planta Med 2015;81:871-871.

104 Gavrish E, Sit CS, Cao S, Kandror O, Spoering A, Peoples A, Ling L, Fetterman A, Hughes D, Bissell A, Torrey H, Akopian T, Mueller A, Epstein S, Goldberg A, Clardy J, Lewis K: Lassomycin, a ribosomally synthesized cyclic peptide, kills Mycobacterium tuberculosis by targeting the ATP-dependent protease ClpC1P1P2. Chem Biol 2014;21:509-518.

105 Brötz-Oesterhelt H, Beyer D, Kroll HP, Endermann R, Ladel C, Schroeder W, Hinzen B, Raddatz S, Paulsen H, Henninger K, Bandow JE, Sahl HG, Labischinski H: Dysregulation of bacterial proteolytic machinery by a new class of antibiotics. Nat Med 2005;11:1082-1087.

106 Ollinger J, O’Malley T, Kesicki EA, Odingo J, Parish T: Validation of the essential ClpP protease in Mycobacterium tuberculosis as a novel drug target. J Bacteriol 2012;194:663-668.

107 Akopian T, Kandror O, Tsu C, Lai JH, Wu W, Liu Y, Zhao P, Park A, Wolf L, Dick LR, Rubin EJ, Bachovchin W, Goldberg AL: Cleavage specificity of Mycobacterium tuberculosis ClpP1P2 protease and identification of novel peptide substrates and boronate inhibitors with anti-bacterial activity. J Biol Chem 2015;290:1100811020.

108 Moreira W, Ngan GJ, Low JL, Poulsen A, Chia BC, Ang MJ, Yap A, Fulwood J, Lakshmanan U, Lim J, Khoo AY, Flotow H, Hill J, Raju RM, Rubin EJ, Dick T: Target mechanism-based whole-cell screening identifies bortezomib as an inhibitor of caseinolytic protease in mycobacteria. mBio 2015;6:e00253-15.

109 Gupta RK, Thakur TS, Desiraju GR, Tyagi JS: Structure-based design of DevR inhibitor active against nonreplicating Mycobacterium tuberculosis. J Med Chem 2009;52:6324-6334. 